\title{
Participatory requirements in forest management planning in Eastern Canada: A temporal and interprovincial perspective
}

\author{
by Nicolas Lecomte ${ }^{1}$, Catherine Martineau-Delisle ${ }^{2}$ and Solange Nadeau ${ }^{3}$
}

\begin{abstract}
With the introduction of the concept of sustainable forest management, the practice of public participation has become omnipresent. This study focuses on provincial participatory requirements in forest management planning (FMP). A comparative framework composed of four participatory process attributes (power, moment of participation, learning/interaction, and procedure) was used to obtain a temporal and interprovincial perspective of Quebec's new participatory process. Our results indicate that with respect to past processes Quebec's current approach allows certain stakeholders, but not the general public, to have more access to FMP. Comparatively, Ontario and Newfoundland have implemented different, clearly stated, approaches that involve the general public at numerous stages of FMP. Future research should concentrate on how these participatory requirements are implemented and on the public satisfaction with regard to this implementation.
\end{abstract}

Key words: public participation, forest management planning, descriptive framework, Canada, Quebec, sustainable forest management

\section{RÉSUMÉ}

La participation du public est devenue un incontournable avec l'introduction du concept de développement forestier durable. Notre étude s'intéresse aux processus de participation publique provinciaux reliés à l'élaboration des plans d'aménagement forestier sur terres publiques et aux exigences légales qui les précèdent. Une analyse comparative de l'approche québécoise actuelle a été effectuée en utilisant un cadre descriptif composé de quatre dimensions d'analyse (pouvoir, moment de la participation, apprentissage/interaction et procédure); celle-ci a été comparée avec ses précédents dispositifs et avec ceux de deux provinces voisines (Terre-Neuve et Ontario). Les résultats indiquent une ouverture du processus décisionnel à de nouveaux acteurs quoiqu'elle soit restreinte à certains groupes d'intérêt plutôt qu'au " grand public ». Les approches retenues par les provinces voisines se distinguent par les occasions multiples qu'elles offrent au " grand public » de prendre part au processus décisionnel relié aux plans. Les études futures devraient explorer la façon dont ces exigences réglementaires sont appliquées et le niveau de satisfaction des participants à l'égard de ces mécanismes.

Mots-clés: participation du public, plans d'aménagement forestier, cadre d'analyse descriptif, forêts publiques, Canada, Québec, gestion forestière durable

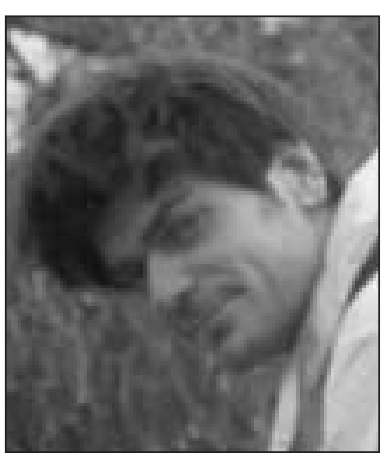

Nicolas Lecomte

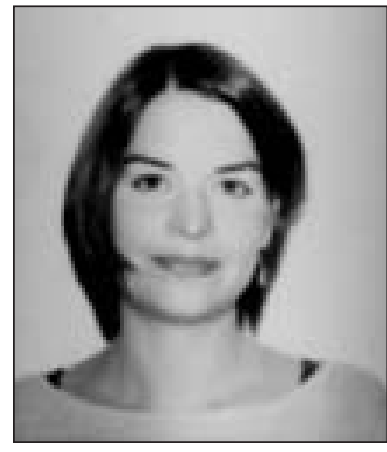

Catherine Martineau-Delisle

${ }^{1}$ Chaire industrielle CRSNG UQAT-UQAM en aménagement forestier durable, Université du Québec en Abitibi-Témiscamingue, 445 Boul. de l'Université, Rouyn-Noranda (Québec) J9X 4E5. E-mail: nicolas.lecomte@uqat.ca

${ }^{2}$ Université Laval (Département de sociologie), Cité universitaire, Québec (Québec) G1K 7P4. E-mail: catherine.martineau-delisle@ soc.ulaval.ca

${ }^{3}$ Ressources Naturelles Canada, Service canadien des forêts Centre de foresterie de l'Atlantique, C.P. 4000, Fredericton (Nouveau-Brunswick) E3B 5P7. E-mail: sonadeau@NRCan.gc.ca

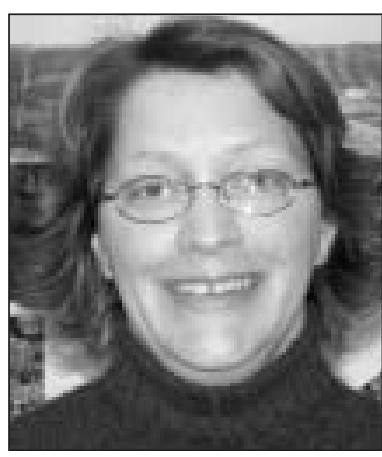

Solange Nadeau

\section{Introduction}

During the 1990s, provincial decision-makers in Canada adopted the concept of sustainable forest management (SFM) in the context of forest management planning (FMP). This has redefined the public's role in FMP. Indeed, public participation (PP) is now an integral component of provincial legislation and SFM criteria-and-indicators systems (e.g., Newfoundland Forest Service 1995, Canadian Council of Forest Ministers 2003). Although there is considerable work on this topic (see Blouin 1998, Duinker 1998), to date there is no systematic description of the provincial approaches to PP in FMP. We believe that future PP approaches can benefit from current and past experience.

This paper focuses mainly on Quebec, which recently has undergone legislative changes to the PP process in FMP (Gouvernement du Québec 2001). A comparative approach provides the means to obtain temporal and inter-provincial 
perspectives on Quebec's new participatory framework. Following this approach, the Quebec PP framework is contrasted with its predecessor and with current PP frameworks in other provinces. Ontario and Newfoundland were chosen because of their geographical proximity, similar tenure systems and hierarchy of management plans and because the majority of their commercial public forests are situated within the eastern boreal biome.

\section{Comparative Framework}

Our study focuses on the provincial legislative requirements pertaining to PP in FMP in public forests under forest tenure. Inspired by the PP literature (e.g., Blahna and Yonts-Shepard 1989, Daniels and Walker 1996, Beierle 1998, Konisky and Beierle 2001), process-level traits, which are reasonably easy to qualify, were chosen to develop a comparative framework composed of four "Participatory Process Attributes" (PPAs): power, moment of participation, learning interaction and procedure. Based on an analysis of the literature and government documents, different provincial participatory requirements were qualified and compared with the PPAs, an approach resembling that of Del Furia and Wallace-Jones (1998) and the Organisation for Economic Cooperation and Development (2001).

The Power PPA refers to the extent of influence citizens have on decisions associated with FMP. Participatory processes imply opening the decision-making process to actors other than traditional ones (i.e., government and industry), which implies more opportunities for "new" actors to influence decisions. To qualify the extent of the public's influence in each participatory approach, we used Arnstein's (1969) typology comprising different "levels" of participation (Table 1).

The Moment of participation PPA is concerned with when (timing) and how often (frequency) citizens are invited to participate in the decision-making process. For this PPA, the overall management process was divided into five stages: 1) elaboration; 2) information; 3) consultation; 4) implementation; and 5) evaluation. We qualified the "timing" of participation by identifying the stages in which the public participates. Frequency refers to how the public is involved in the planning stages: singular (happens once), punctuated (happens at different moments), or continuous (happens in an ongoing fashion).

The Learning interaction PPA refers to the process allowing for exchange of knowledge between participants and for communication and exchange between actors in a more interpersonal sense. It relates to the initiatives that improve everyone's mutual trust and understanding of the range of values, interests, and concerns; for example, mechanisms that allow sustained contact between the participants (e.g., committees, field trips), or that favour the development of constructive dialogue between stakeholders (e.g., ground rules). This PPA was qualified based on three types of interactions: unilateral (from managers to participants); bilateral (from managers to participants and, from participants to managers); and active (dialogue between managers and participants). As participatory processes often distinguish between representatives of interest groups and the general public, we have qualified the Moment of participation and Learning interaction PPAs separately for each type of participant.

Table 1. Eight rungs on a ladder of citizen participation used to qualify the Power PPA (adapted from Arnstein 1969)

8. Citizen Control

7. Delegated Power

6. Partnership

5. Conciliation

4. Consultation

3. Information

2. Therapy

1. Manipulation

Non participatory
Degrees of citizen power

Degrees of citizen influence

The Procedure PPA refers to how the process and its mandate are stated (unclear, clear), and pertains to the functioning of the process and the role of participants in the FMP as well as the formal and legal requirements of the participation exercise. This PPA was evaluated based on the publication of citizen guides to FMP or adherence to clearly stated, jointly approved, ground rules before FMP.

\section{A Temporal Perspective: History of Quebec's Partici- patory Process in FMP}

Quebec's Forest Act was first proclaimed in 1987, and then amended in 1994 and 2001. We describe its participatory approach during three distinct periods (Table 2). The original Forest Act (1987) stated that the public must be informed of the content of management plans on public land. After the tenure holder had deposited the plan at the Ministry, the plan was available for the public to view for 45 days (during business hours at the Ministry or the tenure holder's office). The Power PPA was qualified as information because the public was allowed to view the draft, but was not consulted or able to comment on it. Furthermore, participation occurred only at the information stage (stage 2) and the public was involved only once, after the plan was formulated. The flow of information during this process was unidirectional, i.e., from the beneficiary to the public, and there were few opportunities for the public to interact with the ministry, the beneficiary or each other, thus, there was no interpersonal exchange. This simple participatory process was clearly defined in the Forest Act.

The 1994 Forest Act amendments introduced few changes to Quebec's participatory process (Table 2). However, the public was given the opportunity to comment on the draft (written comment within the first 20 days of the information period), and municipal representatives now had to be personally consulted by tenure holders. A conciliation procedure was also introduced: if there was a conflict, the district manager named a conciliator who had 10 days to resolve it. The public was now involved at specific moments during two stages of the planning process: information and consultation (stages 2 and 3). Although this approach fell near the consultation rung on the ladder of citizen participation, as it occurred very late in the planning process, it could hardly be considered "real consultation" (Tanz and Howard 1990); thus, it fell between the Information and Consultation levels. Furthermore, although the comment and conflict resolution periods 
Table 2. Qualification of the provincial participatory process requirements with respect to four participatory process attributes (see text for explanation)

\begin{tabular}{|c|c|c|c|c|c|c|c|}
\hline \multirow[b]{2}{*}{ Participatory Process Attributes } & \multicolumn{7}{|c|}{ Provincial Processes } \\
\hline & & & $\begin{array}{c}\text { Quebec } \\
1987-1993\end{array}$ & $\begin{array}{c}\text { Quebec } \\
\text { 1993-2001 }\end{array}$ & $\begin{array}{c}\text { Quebec } \\
\text { since } 2001\end{array}$ & Ontario & Newfoundland \\
\hline \multicolumn{3}{|l|}{ 1. Devolution of power } & Information & $\begin{array}{l}\text { Consultation / } \\
\text { Information }\end{array}$ & Conciliation & Conciliation & Partnership \\
\hline \multirow{3}{*}{ 2. Moment of participation } & Representatives & $\begin{array}{l}\text { Timing } \\
\text { Frequency }\end{array}$ & $\begin{array}{c}2 \\
\text { Singular }\end{array}$ & $\begin{array}{c}2,3 \\
\text { Singular }\end{array}$ & $\begin{array}{c}1,2,3 \\
\text { Continuous }\end{array}$ & $\begin{array}{c}1,2,3,4,5 \\
\text { Continuous }\end{array}$ & $\begin{array}{c}1,2,3,4,5 \\
\text { Continuous }\end{array}$ \\
\hline & Public & Timing & 2 & 2,3 & $\begin{array}{c}2,3 \\
\text { Sin }\end{array}$ & $1,2,3,4,5$ & $1,2,3,4,5$ \\
\hline & & Frequency & Singular & Singular & Singular & Punctuated & Continuous \\
\hline \multirow{2}{*}{ 3. Learning interaction } & Representatives & & Unilateral & Bilateral & Active & Active & Active \\
\hline & Public & & Unilateral & Bilateral & Bilateral & Active & Active \\
\hline 4. Procedure & & & Clear & Clear & Unclear & Clear & Clear \\
\hline
\end{tabular}

did allow some opportunity for bilateral exchange of substantive knowledge, there was virtually no face-to-face contact between the different stakeholders, and thus little opportunity for relationship building. As in the original Forest Act, the participatory process to be undertaken was clearly defined.

The 2001 Forest Act amendments increased the comment and conflict resolution periods from 20 to 25 days and from 10 to 20 days, respectively, although the information period remained 45 days. The fundamental change is the adoption of article 54, which states that local interest groups, but not necessarily the general public, must be invited to participate in the development phase of FMP. Specific interest groups are mentioned (municipalities, hunters, outfitters, native communities), but the door is left open to invite other organizations or individuals. Although the general public may still participate during the information and consultation phases (stages 2 and 3), representatives are now involved earlier and continuously from the beginning of the planning process until the final tabling of the plan (stages 1,2, and 3). Quebec's new participatory approach resembles Arnstein's (1969) conciliation strategy of participation, where "a few hand-picked worthy individuals are placed on public bodies." With representatives involved earlier, there are more opportunities for active exchange of knowledge and interpersonal contact among some, but not all, stakeholders (exclusion of the general public in the elaboration stage). Finally, as the recently amended Forest Act does not mention what type of process should be used or define the role of the tenure holder, the Ministry representatives or the general public in FMP, the process and mandate of this approach remain unclear.

\section{An Interprovincial Perspective: Ontario's and New- foundland's Participatory Processes in FMP}

In Ontario, the Ministry of Natural Resources' Class Environmental Assessment for Timber Management on Crown Lands (Government of Ontario 1994) requires that the Ministry establish a Local Citizens Committee (LCC) for each management unit (OMNR 1998). The LCC represents local interests, such as business, hunters, the tourism industry, naturalists, municipalities, native groups, etc. One member of the LCC can be a voting member on the planning team (which includes foresters, fish and wildlife biologists, forest ecologists, and park and fire specialists). LCC members have continuous access to all stages of the process, and the general public is invited to participate at five distinct times during the first three stages, i.e., at the beginning of the planning phase until deposit of the final plan. Anyone who is unsatisfied may suggest another course of action by writing to the plan's author, who will meet with the person to try to resolve the issue. The OMNR District Manager has the final say; if anyone is dissatisfied with the decision they may ask the Minister of Environment and Energy for an environmental assessment of specific forest management activities identified in the plan. Although Ontario's approach is different than Quebec's current process, it also resembles Arnstein's Conciliation level of participation. The LCCs and the five stages including PP create an opportunity for forestry professionals and the general public to meet, and learn about different forestry-related issues and values (Duinker 1998). Finally, OMNR's Guide to Forest Management Planning (OMNR 1998) clearly defines the conflict resolution process, public involvement, and when participation is solicited.

In Newfoundland, the Ministry of Forest Resources and Agrifoods is mandated to include the public in FMP through joint-planning teams for each management district (except in three districts fully allocated to Abitibi-Consolidated; L. Moores, personal communication) (Newfoundland Forest Service 1995). Conflict resolution follows 11 principles of consensus, with a scale of eight levels of agreement (Department of Forest Resources and Agrifoods 2005). However, the district ecosystem manager or tenure holder retains the right to write the plan if consensus cannot be reached. Additionally, 
as anyone can become a member, joint-planning teams allow universal access to the process and, since joint planning teams mutate into joint monitoring teams when the planning process is finished, the public is continuously involved throughout all stages of the planning process (Nazir and Moores 2001). Newfoundland's PP requirements correspond to Arnstein's (1969) partnership strategy of PP, which is described as a process where "power is redistributed through negotiation between citizens and power holders as they agree to share planning and decision-making through such structures as joint planning boards or committees." Joint planning teams offer stakeholders and the general public the opportunity to get to know each other and create an environment primed for active dialogue and deliberation (with some districts having field trips and bi-monthly meetings) (Moores and Duinker 1998). The conflict resolution process, planning team representation, and principles of conduct are all clearly stated in the ground rules at the beginning of the process, and these rules can be modified at any time during the process.

\section{Discussion}

The comparison between Quebec's past and current approaches to PP indicates that the recent legislative changes on public participation in forest management have had many impacts, notably an earlier involvement of representatives in the process and better opportunities for an active exchange of knowledge between the various stakeholders. In comparison with its neighbours, Quebec's current participatory approach differs with respect to several dimensions of public participation in forest management planning.

In Quebec the general public's involvement is limited to after the draft plan is deposited and until the plan is approved, where in Ontario the general public is involved during the elaboration stage and in Newfoundland during all stages of the planning exercise. Moreover, the involvement of representatives in Quebec ends when the final plan is approved whereas in the two other provinces they are continuously involved during the implementation and evaluation stages. Finally, whereas its neighbours have clearly stated how and when participatory processes will be undertaken, Quebec has remained, nearly four years since the passage of the last Forestry Act amendments, ambiguous on this facet of participation.

Quebec's current approach is encouraging: including representatives earlier in the process should give certain citizens more influence in decision-making, and promote opportunities for the active exchange of knowledge and relationship building. Yet there are still some shortcomings, notably regarding the extent of the general public's involvement and the clarity of the mandate and process. As Ontario and Newfoundland have implemented different, clearly stated, participatory approaches that involve the general public at numerous stages of FMP, Quebec may have something to learn from its neighbours about how and when to involve the public in FMP.

\section{Conclusion}

This paper constitutes a first level of analysis as it focuses on some key attributes of the formal requirements regarding PP in FMP. Future studies should explore additional dimensions but also how these requirements are implemented in the actual practice of PP. The entity that organizes and controls the participatory exercise could be an important attribute to incorporate in future comparisons. In Ontario and Newfoundland, the provincial forestry agencies have taken the lead in organizing and chairing public participation processes. In Quebec however, the government has bequeathed this responsibility to the forest industry. If both Ontario and Newfoundland operate under a more rigid framework that does not permit a diversification of participatory processes, on the other hand, Quebec's approach has brought about an undertaking of a variety of different types of PP mechanisms (Nadeau et al. 2004). Although Quebec's approach may facilitate the capacity of participatory processes to adapt to local peculiarities, the delegation of responsibility to the forest industry may engender some conflict of interest, as the forest industry is also an important stakeholder.

Future studies should also analyze participant satisfaction with the implementation of participatory requirements as it is an essential component of the new criteria and indicators system of SFM (Canadian Council of Forest Ministers 2003). Some studies have already indicated that participants in all three provinces are concerned about the representativity of committees and their degree of influence in FMP (Moores and Duinker 1998, OMNR 2002, Nadeau et al. 2004). Eventually, the correlation between the structure of a public participatory process and the public's satisfaction of this process and its outcomes should be understood. This would enable the identification of the multiple dimensions that characterize a socially desirable PP process in FMP and yield suggestions on how provinces can improve their respective participatory practices as they strive to attain SFM.

\section{References}

Arnstein, S.R. 1969. A ladder of citizen participation. American Institute of Planners Journal. 35: 216-224.

Beierle, T.C. 1998. Public participation in environmental decisions: an evaluation framework using social goals. Resources for the Future, Discussion Paper 99-06.Washington, D.C. 34 p.

Blahna, D.J. and S. Yonts-Shepard. 1989. Public involvement in resource planning: toward bridging the gap between policy and implementation. Society and Natural Resources. 2: 209-227.

Blouin, G. 1998. Public involvement processes in forest management in Canada. The Forestry Chronicle. 74 (2): 224-226.

Canadian Council of Forest Ministers. 2003. Defining Sustainable Forest Management in Canada. Criteria and indicators 2003. Ottawa, ON. 30 p.

Daniels, S.E. and G. Walker. 1996. Collaborative learning: improving public deliberation in ecosystem-based management. Environmental Impacts Assessment Review. 16: 71-106.

Del Furia, L. and J. Wallace-Jones. 1998. The effectiveness of provisions and quality of practices concerning public participation in the EIA procedures in Italy and the UK. Social Science Research Network Electronic Paper Collection. 48 p. www.ssrn.com/paper.taf? abstract_id=275134 (accessed November 30, 2002).

Department of Forest Resources and Agrifoods. 2005. District 1: Meeting Ground Rules. http://www.gov.nf.ca/forest/forest/planning/districts/district1/groundrules.htm (accessed November 15, 2002).

Duinker, P. 1998. Public participation's promising progress: advances in forest decision-making in Canada, Commonwealth Forestry Review. 77(2): 107-112.

Government of Ontario. 1994. Crown Forest Sustainability Act. Queen's Printer. Toronto, Ont. http://192.75.156.68/DBLaws/ 
Statutes/English/94c25_e.htm (accessed November 11, 2002).

Gouvernement du Québec. 2001. Bill 136 An Act to Amend the Forest Act and other Legislative Provisions. Quebec Official Publisher. http://publicationsduquebec.gouv.qc.ca/en/frame/index. html (accessed October 26, 2002).

Konisky, D.M. and T.C. Beierle. 2001. Innovations in public participation and environmental decision making: examples from the Great Lakes Region. Society and Natural Resources. 14(9): 815-826. Moores, L. and P.N. Duinker. 1998. Forest planning in Newfoundland: recent progress with public participation. The Forestry Chronicle. 74(6): 871-873.

Nadeau, S., C. Martineau-Delisle and J.-F. Fortier. 2004. Rapport de recherche sur la participation du public à la gestion des forêts québécoises, Mandat d'étude externe réalisé pour la Commission de gestion durable de la forêt québécoise, Québec.

Nazir, M. and L.J. Moores. 2001. Forest policy in Newfoundland and Labrador. The Forestry Chronicle. 77 (1): 61-63.

Newfoundland Forest Service 1995. Environmental Preview Report: Proposed Adaptive Process. Newfoundland Forest Service, Corner
Brook, NL.

Organisation for Economic Cooperation and Development. 2001. Citizens as partners: Information, consultation and public participation in policy-making. http://www.oecd.org (accessed November 30, 2002).

Ontario Ministry of Natural Resources (OMNR). 1998. A Guide to Forest Management Planning. Toronto. Queens Printer of Ontario, Toronto, ON. 20p. http://www.mnr.gov.on.ca/MNR/forsts/fmp_ guide/fmp_guide.html (accessed October 27, 2002).

Ontario Ministry of Natural Resources (OMNR). 2002. A paper for public review concerning the extension and amendment of the Environmental Assessment Act approval for forest management in Ontario. Queen's Printer for Ontario, Toronto, ON. 24 p.

Tanz, J.S. and A.F. Howard. 1990. Meaningful public participation in the planning and management of publicly owned forests. The Forestry Chronicle. 67(2): 125-130. 